\title{
Close Obs
}

I'm curled into a ball on a thin mattress on the floor covered with a crinkly nylon sheet smelling faintly of sick and piss.

Outside the heavy brown door sits Len, muscly, tanned, with the Mirror crossword.

Not much older than me,

he's done his fair share of hurtling down corridors readying needles full of Depixol to slam into the arses of lunatics

like me I suppose.

As my sobbing slows

I hear him humming tunelessly and clicking the end of his pen:

'Mate, your mum said you didn't use to be such a dickhead. Let's see. Try this for starters: French for dead-end, 3-2-3?'

I don't know whether he's smart enough to be taking the mick but I'm damned if this mad man will ever tell him the answer.

\section{David Gilbert}

Correspondence to David Gilbert; davidgilbert43@yahoo.co.uk

Competing interests None.

Provenance and peer review Not commissioned; internally peer reviewed.

Twitter Follow David Gilbert at @DavidGilbert43

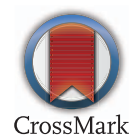

To cite Gilbert D. Med Humanit 2017;43:134

Published Online First 26 September 2016

Med Humanit 2017;43:134. doi:10.1136/medhum-2016-011087.1 